\title{
Welcome to NorDiNa 2/11
}

Welcome to the second issue of NorDiNa this year. As editors we are pleased to inform you that NorDiNa is running well in terms of incoming manuscripts. During the first six months of 2011, we have received 16 manuscripts. In 2010, 25 manuscripts were submitted to NorDiNa and $16 \%$ of these were rejected, $20 \%$ are still in the process, while $64 \%$ of them are now published. In this issue we present in all eight research articles and we are really proud to introduce an issue with authors from all the Nordic countries including Greenland and Faroe Islands!

Also this time the NorDiNa articles span over a wide field and different levels of the educational system. With data from the Swedish ROSE-project, Magnus Oskarsson and KarlGöran Karlsson focus on how interests in different science topics reflect 15-year old students' choice of study program in upper secondary school. They also investigate which interest profiles distinguish science students from other students and conclude that future science students are interested in a broad spectrum of science topics. However, it is future science students' interest in spectacular and dangerous phenomena that separates them from other students. Topics related to health and space are the most popular ones both among future science students and other students.

Students' ideas about the human body are in focus in two of the articles in this issue. Pernilla Granklint Enochson and Andreas Redfors investigate $9^{\text {th }}$ grade students conceptions on how water is transported in the body. Analysis of drawings, questionnaires and interviews show that the students are struggling to relate water transport to the digestive, blood and excretion systems. The other article, by Gunnhildur Óskarsdóttir, Birgitte Stougaard, Ane Fleischer, Eila Jeronen, Finnur Lützen and Roar Kråkenes, is a Nordic case study on 6-8 year old students' conceptions on structure and location of bones and organs. They report both differences and similarities between children from various countries.

This issue also includes two articles on student teachers / novice teachers. Birgitte Lund Nielsen describes novice science teachers' background in science and their argumentation about science teaching. She reports that the novice teachers had a student centered focus related to students' motivation and that they focused on activities as goals in themselves. Sami Lehesvuori, Ilkka Ratinen, Otto Kulhomäki, Jousia Lappi and Jouni Viiri also investigate student teachers conceptions of science teaching, but from another perspective. They are analysing how student teachers develop their conceptualisations of science teaching by following a course combining principles of inquiry and dialogic teaching.

Anna Danielsson looks into the practice of physics as enacted in university student laboratories. With interviews of physics students as data source, she develops two physics student discourse models: "practical physics student" and "analytical physics student". In another article on physics, Antti Laherto addresses the question of incorporating nanoscale science and technology into the secondary school curriculum. Analysis of experienced and nano- 
trained teachers' responses on a questionnaire reveal that they regard nanoscale science and technology as important for citizenship as well as for further studies and science related careers. However, the teachers emphasised the need for in-service training.

Finally, in her article Technological systems in school - on critical aspects as didactic possibilities, Maria Svensson presents a synthesised analysis of two phenomenograpic studies of 10 year olds and 15 year olds experience of technological systems.

This issue also contains a memorial for Professor Phil Scott from the University of Leeds, who has had an important influence on research in Nordic science education.

We spread the abstracts of two more dissertations, and encourage new candidates to submit their abstracts to NorDiNa. Furthermore we include a description of a new book in physics education. In future we encourage authors of books that might be of interest for the NorDiNa readers to send us a copy and we will get a qualified person to write a book review. We are welcoming hints that may improve NorDiNa. One of our readers has requested English titles on articles written in Scandinavian languages. These are now included in the content list.

In June many Nordic science educators were gathered for the tenth Nordic Research Symposium on Science Education held in Linköping. In 2012 NorDiNa will have a special issue with papers from this conference.

At the end of this section we would like to thank the following referees for the excellent work they are doing for NorDiNa. Without them there would be no journal.

Vibe Aarkrog
Maria Andrée
Hanne Møller Andersen
Carl Angell
Frank Bach
Jackie Barber
Sylvia Benckert
Gultekin Cakmakci
Digna Couso
Jens Dolin
Michal Drechsler
Karin Due
Niklas Gericke
Maria Theresa Guerra-Ramos
Cystein Guttersrud
Mats Hagman

Enjoy your read!

$\begin{array}{ll}\text { Ellen K. Henriksen } & \text { Christina Ottander } \\ \text { Magnus Hultén } & \text { Irmeli Palmberg } \\ \text { Kalle Juuti } & \text { Sune Petterson } \\ \text { Christina Kärrqvist } & \text { Andreas Redfors } \\ \text { Tom Klepaker } & \text { Michael Reiss } \\ \text { Erik Knain } & \text { Jim Ryder } \\ \text { Stein Dankert Kolst } \varnothing & \text { Phil Scott } \\ \text { Signild Lemar } & \text { Astrid Sinnes } \\ \text { Svein Lie } & \text { Inga Britt Skog } \\ \text { Cederik Linder } & \text { Helge Strömdahl } \\ \text { Mattias Lundin } & \text { Rie Troelsen } \\ \text { Lena Löfgren } & \text { Sue Dale Tunnicliffe } \\ \text { Claes Malmberg } & \text { Liz Whitelegg } \\ \text { Allyson Mcdonald } & \text { Anna Wikström } \\ \text { Eva Nyberg } & \text { Marianne } \varnothing \text { degaard } \\ \text { Helena Näs } & \end{array}$

Sonja M. Mork

Christina Ottander

Svein Sjøberg 